\title{
Rethinking Space Design Standards Toward Quality Affordable Housing In Malaysia
}

\author{
Nor Haniza Ishak ${ }^{1,}$, Ati Rosemary Mohd Ariffin ${ }^{2}$, Raha Sulaiman ${ }^{3}$ and Muhammad Najib Mohd Zailani ${ }^{4}$ \\ 1, 2, 3, 4 Faculty of Built Environment, University of Malaya, 50603 Kuala Lumpur MALAYSIA
}

\begin{abstract}
Provision of affordable housing is important to low- and middle-income population. A fit form of house will not only fulfil a basic human need for shelter, but it also contributes to physical and psychological well-being of the occupants. Excellent quality and affordable housing is an indication of a high quality of life. While writings exist on various aspects of the quality of affordable housing in Malaysia, discussion regarding space and design standards has scarcely been given any serious academic attention. Standards concerning residential development usually cover different aspects or stages of the development process. They can include planning standards, design standards, space standards and technical construction standards. The main concern of this paper is on space and design standards specifically. Space standard can be defined as a set of framework which dictates fixed internal space minimums. Meanwhile, design standard indicates design guidelines to ensure the functionality, comfortability and habitability of the house. This paper is concerned exclusively with indoor spaces of a house excluding external circulation spaces and service facilities (in case of strata housing). Its interest is in internal space as an aspect of housing quality. It can be concluded that one of the way forward will be to find the balance between providing adequate minimum spaces for resident satisfactions and having economic values for housing developers. This paper may be used as a valuable reference for authorities and policy makers to better address the best housing space design standards that would benefit not only the occupants, but also the local government and developers alike.
\end{abstract}

\section{Introduction}

Malaysia is a federal constitutional monarchy located in central Southeast Asia, bordering Thailand to the north and Singapore to the south. It consists of thirteen states and three federal territories and has a total landmass of 329,847 square kilometres with the estimated population of 29.90 million people [1]. Malaysia gain Independence through peaceful negotiation from the reign of British administration in 1957. The 2014/2015 Economic Report released by the Finance Ministry shows that Malaysian per capita income in purchasing power parity terms is projected at US\$23,512. After the British Colonisation period, the Malaysian government played its vital role in devising and creating various national policies to improve the economic development, political stability and social welfares of the nation.

Among the most well-known national policies in Malaysia are the Five Yearly National Development Plans, a comprehensive economic development blueprint where the Economic Planning Unit of the Prime Minister's Department is being entrusted with the task of preparing it. The early Malaysia's Economic Plans in providing low cost housing was a profound strategy to include the rural Malays to migrate to urban areas.

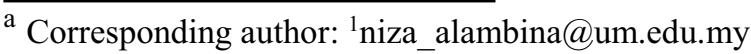

\subsection{Concept of affordable housing}

In this ever-changing, globalize world, it is envision that a house would be a sanctuary where one could find solace and tranquilities from the pressing reality of living. For many years the mass housing was modelled after the British houses and its standards and By-Laws, remnant of colonial days. Standards currently in use frequently date back to colonial times and all too often reflect the present day standards in use the former coloniser [2].

Since the beginning, the government had identified housing as a crucial and basic social need and had taken responsibility in ensuring adequate provision of affordable housing to all strata of the societies. The term 'affordable housing' at its simplest connotation, refers to the financial affordability of housing with respect to the occupants' incomes [3].

\subsection{Low-cost housing in Malaysia}

Providing housing for the low income people, particularly the urban poor has always been a fundamental part of the state's housing policy to maintain the stability and prosperity of the country. The 
commitment by the Malaysian government to provide adequate and affordable shelter for its nation was evidently reflected in the government's annual budget and the nation Five Yearly Development Plans [4]. The early main concern of the housing policies in Malaysia is to provide home-owning democracy to all of its citizens, simultaneously eradicating hardcore poverty and urban squatter problem [5]. Under this root principle, the government and latter, the private sector had delivered massive amounts of low-cost housing under various affordable housing schemes such as Housing for the hardcore poor (PPRT), People Housing Project (PPR), 1Malaysia Civil Servants Housing (PPA1M) and Schemes under Syarikat Perumahan Negara Berhad (SPNB) to name a few.

Malaysia is now in the transition period between the Tenth Malaysia Plan (2011-2015) and the Eleventh Malaysia Plan (2016-2020). In the span of 50 years the government had improved by leaps and bounds in the provision of affordable low-cost housings via both public and the private sector despite still not being enough [6] and had addressed many issues and problems pertaining to matter such as financing of the mortgage loan, reducing construction cost and upgrading the provision system to legitimate low income population.

Previously, the public housing developers only concern on achieving their anticipated outcomes target. Most of the houses are very basic in nature and little attention was paid to quality. In term of quality the type of housing has not been satisfactory to the family's housing needs, comfort, social, cultural and religious needs $[7,8]$. However, in the last couple of decades the government had a pivotal shift in its housing policies from delivering quantities to ensuring qualities. This is evidently outlined in the Tenth Malaysia Plan (RMK10). One of the main objectives in Chapter 6 is to "ensure access to quality and affordable housing" and with it highlighted three major challenges that need to be overcome. The first underlying challenge is the apparent mismatch between supply and the massive demand of low-cost housing [9]. The second challenge outlined in RMK10 is to meet the call for environmentally sustainable design. The last challenge, which is also the concern of this paper, is to increase the quality of affordable new and existing housing.

'Weak quality controls during construction and poor maintenance have contributed to a decline in the quality of affordable housing. During the Plan period, existing laws, including the Uniform Building By-Laws 1984, will be reviewed to incorporate minimum specifications of housing quality, particularly on ensuring quality in the provision of affordable housing developments' (Chapter 6, Tenth Malaysia Plan, 2011).

The government's vision of providing quality affordable housing is also being translated in the latest Eleventh Malaysia Plan (2016-2020). However, the policy emphasizes on providing adequate and quality affordable housing not only for the poor, low-income but also for the middle-income households with differing levels of support based on need. This is due to the fact that Malaysia is aiming to become a selfsufficient industrialized nation by the year 2020, and the government recognized affordable housing as a crucial platform that creates strong and stable communities, with better economic, education, and health outcomes for individuals, families and communities [10]. The low- and middle-income households also constitute for a big slice of Malaysia's population. The recentlyannounced 2016 Annual Budget categorized both of these household classes into B40 (Bottom 40) and M40 (Middle 40) respectively, indicating each classes making up $40 \%$ of the overall national population.

\subsection{Quality affordable housing}

Ultimately, it is everyone's dream to have at least a decent quality of life. The subject of quality of life is very diverse, complicated and is hard to be quantified. There are often many factors that come into play. Nonetheless, there are a few indicators that can be used such as social, well-being measures and economic indicators [11]. The Malaysian government had given attention to provide its citizen with good quality of life and is evident in which three of seven Malaysia strategic thrusts (in RMK10), namely, (1) building an environment that enhances the quality of life, (2) moving towards inclusive socio-economic development, and (3) creating the environment for unleashing economic growth, have a direct relation to Malaysian housing [9].

However, the term 'quality housing' is too generic and comprises of several broader elements such as construction quality, facility managements quality, neighborhood quality, public hygiene \& safety quality and lastly, internal housing space quality. Excellent quality and affordable housing is an indication of a high quality of life. It not only fulfils a basic human need for shelter, but it also contributes to physical and psychological well-being of the occupants. While writings exist on various aspects of the quality of affordable housing in Malaysia, discussion regarding space design standards has scarcely been given any serious academic attention. Therefore, it is our intention in this paper to focus on one of the facets of quality housing which is the internal housing space quality, paying particular attention to the government's policies and regulations of space design standards. This paper is concerned exclusively with indoor spaces of a housing unit excluding external circulation spaces and service facilities in strata developments such as flats and apartments. We will explore the importance of rethinking the current space design standards and also the potential setbacks if such moves were taken.

\section{Space design standards in Malaysia}

Standards of Malaysia Act 1996 (Act 549) defines standard as a document approved by a recognized body, that provides, for common and repeated use, rules, guidelines or characteristics for product or related 
processes and production methods, with which compliance is not mandatory; and which may also include or deal exclusively with terminology, symbols, packaging, marking or labelling requirements as they apply to a product, process or production method. Interestingly enough, standards, under the law is not mandatory and becomes more like a guideline, unless explicitly stated that compliance is mandatory. However, a standard only become mandatory when a regulatory agency enforces its use through the relevant Act and Regulations.

Standards concerning residential development usually cover different aspects or stages of the development process. They can include planning standards, design standards, space standards and technical construction standards. All of these standards are crucial as a mean of measuring the quality of the physical construction integrity and also the psychological wellbeing promoted by the housing development.

Space standard can be defined as a set of framework which dictates fixed internal space minimums. Basic rules govern the quantity of living space that must be provided, minimum acceptable ceiling heights, and ventilation and light requirements and so on [12]. Meanwhile, design standard indicates design guidelines that need to be followed in order to ensure that all housing units are functional, comfortable and fit to be inhabited [13]. Design standards usually address the minimum requirements for the spaces or rooms to function well such as the water retention system, electrical and gas installation, internal wiring for telephone, sanitary waste disposal system, health and safety, security and plumbing fixture.

Currently in Malaysia there are only one law that have provision on space and design standards. It is the Uniform Building By-Law 1984 (UBBL 1984). The UBBL 1984 prescribes plan submission procedures, provisions on space and design methods, temporary works provisions, construction requirements, structural requirements, fire requirements, alarm, detection, extinguishment, and access, and other miscellaneous items. Part III of the UBBL 1984 talks specifically on the required space [dimensions], natural light and ventilation to be provided in buildings [14].

Since 1981, the Ministry of Housing and Local Government has introduced and implemented a concept of low-cost housing incorporating the following characteristics, (1) selling price not exceeding RM25, 000 per unit, (2) Targeting households with a monthly income not exceeding RM750, (3) type of houses ranging from flats, single-storey terrace to detached houses and (4) minimum design standard with built-up area of 550-600 square feet, two bedrooms, a living room, a kitchen and a bathroom-cum-toilet [5]. Realising that the need for housing standards would arise, the Construction Industry Development Board (CIDB), a statutory body established under the Parliamentary Act 520 (Construction Industry Development Board of Malaysia Act 1994) together with the Ministry of Housing and Local Government had set up a technical committee to come out with a National Housing Standards series. It initially started as two volumes; Construction Industry Standard 1 for Single/Double-Storey Low-Cost House and Construction Industry Standards 2 for Low-Cost Apartment. Both are established in 1998. Abdul Mohit [15] accounted that in 2002 the low-cost housing design in Malaysia has undergone changes from the provision of two bedrooms to three bedrooms with the addition of a dining room, a separate bathroom and a toilet, and a drying area. The new revision is also to accommodate to social and cultural preferences such as the need to separate children of different gender from sharing rooms. Hence it is necessary to have at least 3-bedroom units in low-cost housing schemes [5].

Despite great contribution from the private sectors in helping the government building low-cost houses, there had been constant complaints and arguments that the required allocation of at least $30 \%$ low-cost houses in their housing projects are pegged at the ceiling price of RM25, 000 by the government for all types of lowcost houses, irrespective of their location and typology is not enough for them to have a profit return and also deliver good quality housing [16]. In order to improve the quality of low-cost houses and simultaneously meet private developer's argument for a review of the selling prices of these units the government has introduced in 2002 the new pricing guideline for this type of houses. With the new selling prices of low-cost houses, it is to be expected that the design specifications be revised too [5]. The new design specifications are summarized in Table 1 .

In 2005, CIDB proposed some new addition to the National Housing Standards which is CIS 3 and CIS 4. Both standards emphasized on lower middle-cost houses such that CIS 3 is for lower middle-cost houses other than apartment and CIS 4 is for lower middle-cost apartment. This is in line with the government's intention as stated in the Ninth Malaysia Plan (20062010) in providing sustainable urban development and adequate housing for all income groups taking into account not only provision for low-cost house but also the delivery of middle-cost and high end property. Since the provision of middle-cost houses were entrusted solely to the private developers it is necessary for the government to establish a mandatory standard that would regulate such developments [5]. This prompted CIDB to introduce CIS 3 and CIS 4 into the National Housing Standard.

It is only recently that the government gazette PR1MA Act 2012 and establishes Perbadanan PR1MA Malaysia to plan, develop, construct and maintain highquality housing with lifestyle concepts for middleincome households in key urban centres. However PR1MA Malaysia developed their own set of standards to be complied by all of their high-rise developments. Table 2 illustrates the compilation of all space design standards concerning strata developments in Malaysia. 
Table 1. Low-Cost Houses: New Design Specifications

\begin{tabular}{|c|c|c|}
\hline Elements & Terrace Houses & Flats \\
\hline Floor Space & $48-60 \mathrm{~m}^{2}$ & $45-56 \mathrm{~m}^{2}$ \\
\hline Bedroom & & \\
\hline $\begin{array}{l}\text {-minimum number } \\
\text {-minimum area of habitable } \\
\text { room: }\end{array}$ & 3 & 3 \\
\hline (i) First Room & $11.7 \mathrm{~m}^{2}$ & $11.7 \mathrm{~m}^{2}$ \\
\hline (ii) Second Room & $9.9 \mathrm{~m}^{2}$ & $9.9 \mathrm{~m}^{2}$ \\
\hline (iii) Third Room & $7.2 \mathrm{~m}^{2}$ & $7.2 \mathrm{~m}^{2}$ \\
\hline Kitchen-minimum area & $4.5 \mathrm{~m}^{2}$ & $4.5 \mathrm{~m}^{2}$ \\
\hline Living and dining rooms & $\begin{array}{l}\text { Provided as one combined space or seperately } \\
\text { with adequate area according to internal } \\
\text { layout. }\end{array}$ & $\begin{array}{l}\text { Provided as one combined space or } \\
\text { seperately with adequate area according to } \\
\text { internal layout. }\end{array}$ \\
\hline Bathroom and Toilet & $\begin{array}{l}\text { Provided seperately with minimum area of } \\
1.8 \mathrm{~m}^{2} \text { each. }\end{array}$ & $\begin{array}{l}\text { Provided seperately with minimum area of } \\
1.8 \mathrm{~m}^{2} \text { each. }\end{array}$ \\
\hline Storage space and porch & Adequate provision for resident's comfort. & $\begin{array}{l}\text { Adequate provision for resident's } \\
\text { convenience and comfort. }\end{array}$ \\
\hline $\begin{array}{l}\text { Drying Area } \\
(*) \text { Laundrette facilities }\end{array}$ & - & Adequate provision for each unit. \\
\hline
\end{tabular}

Note: $\left(^{*}\right)$ Must be provided according to the 'Guidelines for the provision of laundrette facilities in multi-storey buildings' prepared by Local Government Department, Ministry of Housing and Local Government.

Source: Ministry of Housing and Local Government, 2002

Table 2. Compilation of Space Design Standard in Malaysia

\begin{tabular}{|c|c|c|c|c|c|}
\hline $\begin{array}{c}\text { NAME OF } \\
\text { STANDARD }\end{array}$ & $\begin{array}{c}\text { TYPE OF } \\
\text { PROPERTY }\end{array}$ & SPACE STANDARDS & DESIGN STANDARDS & $\begin{array}{c}\text { YEAR OF } \\
\text { ENACTMENT }\end{array}$ & $\begin{array}{c}\text { LATEST } \\
\text { REVISION }\end{array}$ \\
\hline $\begin{array}{l}\text { Uniform } \\
\text { Building By- } \\
\text { Laws } 1984\end{array}$ & $\begin{array}{l}\text { Residential } \\
\text { Building }\end{array}$ & $\begin{array}{l}\text { Minimum area for rooms in } \\
\text { residential buildings: } \\
-1^{\text {st }} \text { habitable Bedroom: not less } \\
\text { than } 11 \mathrm{~m}^{2} \\
-2^{\text {nd }} \text { habitable Bedroom: not less } \\
\text { than } 9.3 \mathrm{~m}^{2} \\
-3^{\text {rd }} \text { habitable Bedroom: not less } \\
\text { than } 6.5 \mathrm{~m}^{2} \\
\text {-The width of every habitable } \\
\text { room in residential building shall } \\
\text { be not less than } 2 \mathrm{~m} \text {. } \\
\text {-The area and width of a kitchen } \\
\text { in a resident building shall be not } \\
\text { less than } 4.5 \mathrm{~m}^{2} \text { and } 1.50 \mathrm{~m}^{2} \\
\text { respectively. } \\
\text {-In all buildings, the sizes of } \\
\text { latrines, water closets and } \\
\text { bathrooms shall be- } \\
\text { (a) in the case of latrines or water- } \\
\text { closet with pedestal-type closet } \\
\text { fittings, not less than } 1.50 \mathrm{~m} \text { by } \\
0.75 \mathrm{~m} \text {; } \\
\text { (b) in the case of water-closet } \\
\text { with fittings other than pedestal- } \\
\text { type closet fitting, not less than } \\
1.25 \mathrm{~m} \text { by } 0.75 \mathrm{~m} \text {; } \\
\text { (c) in the case of bathrooms, not } \\
\text { less than } 1.5 \mathrm{~m}^{2} \text { with a width of } \\
\text { not less than } 0.75 \mathrm{~m} \text {; } \\
\text { (d) in the case of bathrooms with } \\
\text { water closet fittings, not less than } \\
2 \mathrm{~m}{ }^{2} \text { with a width of not less than } \\
0.75 \mathrm{~m} . \\
\text { Height: } \\
- \text { The height of rooms in } \\
\text { residential buildings other than } \\
\text { shop houses shall be: }\end{array}$ & $\begin{array}{l}\text { Natural Lighting \& Ventilation: } \\
\text {-Every room designed, adapted or } \\
\text { used for residential, business or } \\
\text { other purposes except hospitals } \\
\text { and schools shall be provided } \\
\text { with natural lighting and natural } \\
\text { ventilation by means of one or } \\
\text { more windows having a total area } \\
\text { of no less than } 10 \% \text { of the clear } \\
\text { floor area of such room and shall } \\
\text { have openings capable of } \\
\text { allowing a free uninterrupted } \\
\text { passage of air of not less than } 5 \% \\
\text { of such floor area. } \\
\text {-Every water-closet, latrine, urinal } \\
\text { or bathroom shall be provided } \\
\text { with natural lighting and natural } \\
\text { ventilation by means of one or } \\
\text { more openings having a total area } \\
\text { of not less than } 0.2 \mathrm{~m}^{2} \text { per water- } \\
\text { closet, urinal latrine or bathroom } \\
\text { and such openings shall be } \\
\text { capable of allowing a free } \\
\text { uninterrupted passage of air. }\end{array}$ & $\begin{array}{l}1976 \\
\text { 1984- gazetted } \\
\text { as UBBL } 1984\end{array}$ & $\begin{array}{l}\text { 2007- to } \\
\text { incorporate } \\
\text { the } \\
\text { amendments } \\
\text { to the Street, } \\
\text { Drainage \& } \\
\text { Building Act, } \\
\text { 1974 with } \\
\text { regard to the } \\
\text { Certificate of } \\
\text { Completion } \\
\text { and } \\
\text { Compliance } \\
\text { (CCC) } \\
\text { 2012- } \\
\text { Amendments } \\
\text { on Energy } \\
\text { Efficiency } \\
\text { ByLaw and } \\
\text { MS1525:2014 }\end{array}$ \\
\hline
\end{tabular}




\begin{tabular}{|c|c|c|c|c|c|}
\hline & & $\begin{array}{l}\text { (a) Living rooms \& Bedrooms: } \\
\text { not less than } 2.5 \mathrm{~m} \text {. } \\
\text { (b) Kitchens: not less than } 2.25 \mathrm{~m} \text {. } \\
\text { (c) Bathroom, water-closets, } \\
\text { latrines, porches, balconies, } \\
\text { verandahs, garages and the like: } \\
\text { not less than } 2 \mathrm{~m} \text {. } \\
\text {-The average height of rooms } \\
\text { with sloping ceilings in } \\
\text { residential buildings other than } \\
\text { shop houses should be the same } \\
\text { as above provided that no part of } \\
\text { any room shall be less than } 2 \mathrm{~m} \text { in } \\
\text { height. }\end{array}$ & & & \\
\hline $\begin{array}{l}\text { Construction } \\
\text { Industry } \\
\text { Standard } 2 \\
: 1998\end{array}$ & Low-cost flat & $\begin{array}{l}\text { Floor Area: } \\
\text {-Minimum three (3) Bedrooms } \\
1^{\text {st }} \text { Bedroom : not less than } \\
11.7 \mathrm{~m}^{2} \\
2^{\text {nd }} \text { Bedroom: not less than } 9.9 \mathrm{~m}^{2} \\
3^{\text {rd }} \text { Bedroom: not less than } 7.2 \mathrm{~m}^{2} \\
\text {-Kitchen: not less than } 5.4 \mathrm{~m}^{2} \\
\text {-Living and Dining Room can be } \\
\text { combined or separated. } \\
\text {-Separate Bathroom and Toilet } \\
\text { Bathroom: not less than } 1.8 \mathrm{~m}^{2} . \\
\text { Minimum width of space should } \\
\text { be not less than } 1.2 \mathrm{~m} \text {. } \\
\text { Toilet: not less than } 1.8 \mathrm{~m}^{2} . \\
\text { Minimum width of space should } \\
\text { be not less than } 1.2 \mathrm{~m} \text {. } \\
\text {-Adequate storage are and } \\
\text { circulation space together with a } \\
\text { covered space for drying clothes } \\
\text { must be provided for the comfort } \\
\text { of the occupants. } \\
\text { Residential Unit Size: } \\
- \text { Residential units need to have } \\
\text { front opening and adequate size to } \\
\text { ensure the internal space can be } \\
\text { used efficiently and has good } \\
\text { natural ventilation for the comfort } \\
\text { of the occupants. Must be not less } \\
\text { than } 63 \mathrm{~m}{ }^{2} \text {. } \\
\text {-minimum front opening for } \\
\text { residential unit is } 6 \mathrm{~m} \text {. } \\
\text { Height: } \\
- \text { Bedroom and Living/Dining } \\
\text { Room: Height must be not less } \\
\text { than } 2.8 \mathrm{~m} . \\
\text {-Kitchen: Height must be not less } \\
\text { than } 2.8 \mathrm{~m} . \\
\text {-Bathroom/Toilet: Height must be } \\
\text { not less than } 2.5 \mathrm{~m} . \\
\text {-The average height for } \\
\text { room/spaces with sloped ceiling } \\
\text { must be the same as previously } \\
\text { stated unless, with condition that } \\
\text { no part of the room can be lower } \\
\text { than } 2 \mathrm{~m} \text { in height. }\end{array}$ & $\begin{array}{l}\text { Finishes \& Fixtures: } \\
\text {-Floor and wall finishes for all the } \\
\text { internal spaces are provided in the } \\
\text { document. } \\
\text { Natural Ventilation \& Lighting: } \\
\text {-All the rooms/spaces provided in } \\
\text { each of the units need to receive } \\
\text { natural lighting and ventilation } \\
\text { through one or more windows } \\
\text { with opening no less than } 10 \% \text { of } \\
\text { rooms/spaces area and need to } \\
\text { have opening no less than } 5 \% \text { of } \\
\text { rooms/spaces area that would } \\
\text { allow for unrestricted circulation } \\
\text { of air. Cross ventilation is highly } \\
\text { recommended, and should as } \\
\text { much as possible cover all rooms } \\
\text { and from the front till the back or } \\
\text { vice-versa. } \\
\text { Dividing Walls: } \\
\text { Dividing walls have to be built in } \\
\text { between each unit and need to be } \\
\text { built all the way to the roof and } \\
\text { have fire-resistant property of at } \\
\text { least two (2) hours. } \\
\text { *all of the building's design } \\
\text { dimensions have to follow MS } \\
1064 \text { - Guide To Modular } \\
\text { Coordination in Building } \\
\text { specification. }\end{array}$ & 1998 & $\begin{array}{l}2002- \\
\text { Improvement } \\
\text { of size of } \\
\text { space due to } \\
\text { the } \\
\text { introduction } \\
\text { of new low- } \\
\text { cost houses } \\
\text { pricing by } \\
\text { governement }\end{array}$ \\
\hline $\begin{array}{l}\text { Construction } \\
\text { Industry } \\
\text { Standard } 4 \\
: 2005\end{array}$ & $\begin{array}{l}\text { Lower } \\
\text { middle-cost } \\
\text { flat }\end{array}$ & $\begin{array}{l}\text { Floor Area: } \\
\text {-Minimum three (3) Bedrooms } \\
1^{\text {st }} \text { Bedroom : not less than } \\
12.8 \mathrm{~m}^{2} \\
2^{\text {nd }} \text { Bedroom: not less than } \\
11.8 \mathrm{~m}^{2} \\
3^{\text {rd }} \text { Bedroom: not less than } 9.9 \mathrm{~m}^{2} \\
\text {-Kitchen: not less than } 6 . \mathrm{m}^{2}\end{array}$ & $\begin{array}{l}\text { Finishes: } \\
\text {-Floor and wall finishes for all the } \\
\text { internal spaces are provided in the } \\
\text { document. } \\
\text { Natural Ventilation \& Lighting: } \\
\text {-All the rooms/spaces provided in } \\
\text { each of the units need to receive } \\
\text { natural lighting and ventilation }\end{array}$ & 2005 & $\begin{array}{l}\text { No known } \\
\text { revision }\end{array}$ \\
\hline
\end{tabular}




\begin{tabular}{|c|c|c|c|c|c|}
\hline & & $\begin{array}{l}\text {-Living and Dining Room can be } \\
\text { combined or separated. } \\
\text {-Separate Bathroom and Toilet. } \\
\text { Bathroom/ Toilet: not less than } \\
2.7 \mathrm{~m}^{2} . \text { Minimum width of space } \\
\text { should be not less than } 1.5 \mathrm{~m} \text {. } \\
\text {-Adequate storage are and } \\
\text { circulation space together with a } \\
\text { covered space for drying clothes } \\
\text { must be provided for the comfort } \\
\text { of the occupants. } \\
\text { Residential Unit Size: } \\
\text {-Residential units need to have } \\
\text { front opening and adequate size to } \\
\text { ensure the internal space can be } \\
\text { used efficiently and has good } \\
\text { natural ventilation for the comfort } \\
\text { of the occupants. Must be not less } \\
\text { than } 70 \mathrm{~m}^{2} \text { excluding balcony and } \\
\text { drying area. } \\
\text {-minimum front opening for } \\
\text { residential unit is } 6 \mathrm{~m} . \\
\text { Height: } \\
\text {-Bedroom and Living/Dining } \\
\text { Room: Height must be not less } \\
\text { than } 2.8 \mathrm{~m} \text {. } \\
\text {-Kitchen: Height must be not less } \\
\text { than } 2.4 \mathrm{~m} \text {. } \\
\text {-Bathroom/Toilet: Height must be } \\
\text { not less than } 2.4 \mathrm{~m} \text {. } \\
\text {-The average height for } \\
\text { room/spaces with sloped ceiling } \\
\text { must be the same as previously } \\
\text { stated unless, with condition that } \\
\text { no part of the room can be lower } \\
\text { than } 2 \mathrm{~m} \text { in height. }\end{array}$ & $\begin{array}{l}\text { through one or more windows } \\
\text { with opening no less than } 10 \% \text { of } \\
\text { rooms/spaces area and need to } \\
\text { have opening no less than } 5 \% \text { of } \\
\text { rooms/spaces area that would } \\
\text { allow for unrestricted circulation } \\
\text { of air. Cross ventilation is highly } \\
\text { recommended, and should as } \\
\text { much as possible cover all rooms } \\
\text { and from the front till the back or } \\
\text { vice-versa. } \\
\text {-Minimum size of air wells } \\
\text { should be in accordance to the } \\
\text { Uniform Building By-Law } 1984 \text {, } \\
\text { Part } 3 \text {, Clause } 40 \text { (including } \\
\text { revisions). } \\
\text { Dividing Walls: } \\
\text { Dividing walls have to be built in } \\
\text { between each unit and need to be } \\
\text { built } 225 \text { mm extending the roof } \\
\text { level in accordance to the } \\
\text { Uniform Building By-Law } 1984 \\
\text { (including revisions) and the } \\
\text { requirement from Fire and Rescue } \\
\text { Department of Malaysia. } \\
\text { *All of the building's design } \\
\text { dimensions have to follow MS } \\
1064 \text { - Guide To Modular } \\
\text { Coordination in Building } \\
\text { specification. } \\
\text { *Design and unit layout have to } \\
\text { be 'user-friendly' by following } \\
\text { the Garis Panduan Perancangan } \\
\text { Golongan Orang Kurang Upaya, } \\
\text { Jabatan Perancangan Bandar } \\
\text { dan Desa } 1 / 2000 \text { and Standard } \\
\text { Malaysia, SIRIM MS } 1331 \text { (Code } \\
\text { of Practice for Access for } \\
\text { Disabled People Outside } \\
\text { Buildings). }\end{array}$ & & \\
\hline $\begin{array}{l}\text { PR1MA } \\
\text { Project Brief } \\
\text { 2015; Section } \\
\text { 1, Planning } \\
\text { and Built- } \\
\text { Form } \\
\text { Requirements } \\
\text { - High Rise }\end{array}$ & Apartment & $\begin{array}{l}\text { Residential Unit Size: } \\
\text {-For all PR1MA's high rise } \\
\text { developments, six types of } \\
\text { apartment unit are required as } \\
\text { follows: } \\
\text { Preferred unit type: } \\
\text { 2+1 Bedroom: } 78.9 \mathrm{~m}^{2} \pm 5 \% \\
3 \text { Bedroom: } 92.9 \mathrm{~m}^{2} \pm 5 \% \\
3+1 \text { Bedroom: } 111.48 \mathrm{~m}^{2} \pm 5 \% \\
\text { Situational unit type: } \\
\text { Studio: } 51.09 \mathrm{~m}^{2} \pm 5 \% \\
1+1 \text { Bedroom: } 60.4 \mathrm{~m}^{2} \pm 5 \% \\
2 \text { Bedroom: } 69.68 \mathrm{~m}^{2} \pm 5 \% \\
\text {-The spatial hierarchy within all } \\
\text { PR1MA residential units have the } \\
\text { following characteristic: } \\
\text { (a) Bedrooms are preferred to } \\
\text { have windows facing outwards. } \\
\text { (b) Yard to connect kitchen into a } \\
\text { semi-private corridor and a } \\
\text { bathroom }\end{array}$ & $\begin{array}{l}\text { Must be provided according to } \\
\text { 'Book 2a- High Rise Minimal } \\
\text { Standard for detailed } \\
\text { guidelines' prepared by } \\
\text { Perbadanan PR1MA Malaysia. }\end{array}$ & 2015 & No revision \\
\hline
\end{tabular}




\section{Lessons from other countries}

\subsection{Calculating Standards of Floor Area based on Living Density of Housing Units}

In the span of this research we are still yet to come across with any national statistic on floor area of housing per number of households and the average floor area per person in Malaysia. Using average floor area per person can give us insights of the potential overcrowding problems and indentify the gap in the allocation of free space amongst the lowest-income households to the highest-income households. A small average figure would imply that the majority of the population are living in potentially overcrowded small houses while a big average figure indicates that most of the national population are enjoying ample space for living. This indicator is commonly used by major developed countries such as the United Kingdom and Japan. Table 3 and Table 4 indicate the use of average floor area per person in respect to data from Japan.

Table 3. Standards of Floor Area $\left(\mathrm{m}^{2}\right)$ and Living Density $\left(\mathrm{m}^{2}\right.$ per person) of Housing Units

\begin{tabular}{|c|c|c|}
\hline $\begin{array}{c}\text { Size of } \\
\text { households } \\
\text { (persons) }\end{array}$ & $\begin{array}{c}\text { Floor area per } \\
\text { housing } \\
\left.\text { unit } \mathbf{( m}^{\mathbf{2}}\right)\end{array}$ & $\begin{array}{c}\text { Implied density } \\
\text { of housing } \\
\text { unit } \mathbf{( m}^{\mathbf{2}} \mathbf{~ p e r} \\
\text { person) }\end{array}$ \\
\hline 1 & 18 & 18 \\
\hline $1($ elderly) & 25 & 25 \\
\hline 2 & 29 & 14.5 \\
\hline 3 & 39 & 13 \\
\hline 4 & 50 & 12.5 \\
\hline 5 & 56 & 11.2 \\
\hline 6 & 66 & 11 \\
\hline Source: The Building Center of Japan, A Quick Look at Housing in \\
\multicolumn{2}{|c|}{ Japan }
\end{tabular}

Table 4. Average floor area per person in Japan $\left(\mathrm{m}^{2}\right.$ per person)

\begin{tabular}{|l|c|c|c|c|c|c|c|}
\hline & $\mathbf{1 9 6 3}$ & $\mathbf{1 9 6 8}$ & $\mathbf{1 9 7 3}$ & $\mathbf{1 9 7 8}$ & $\mathbf{1 9 8 3}$ & $\mathbf{1 9 8 8}$ & $\mathbf{1 9 9 3}$ \\
\hline $\begin{array}{l}\text { Floor } \\
\text { area } \\
\text { per } \\
\text { person }\end{array}$ & 17.3 & 19.0 & 21.5 & 23.3 & 25.8 & 28.0 & 30.9 \\
\hline
\end{tabular}

Source: The Building Center of Japan, A Quick Look at Housing in Japan

It is worth noting that the average floor area per person in Japan was $30.9 \mathrm{~m}^{2}$ in 1993 which is an impressive improvement from the average of $17.3 \mathrm{~m}^{2}$ per person in 1963. There are some potential benefits if our current standards adopted the Living Density of Housing Units indicator.

\subsection{Classification system for current typology of affordable housings}

To date, the government has introduced various public housing schemes. Among them are Program Bantuan Rakyat (PBR), Program Perumahan Rakyat (PPR), Rumah Mesra Rakyat IMalaysia (RMR1M), Perumahan Rakyat 1Malaysia (PR1MA), 1Malaysia Civil Servants Housing (PPA1M) and Rumah Wilayah Persekutuan (RUMAWIP). However, not all of these schemes are low-cost housings. For instance, PR1MA scheme is the government's initiative to provide housings for middle-income group since they are not eligible to apply for low-cost houses but are unable to afford houses offered by the mainstream property market.

The first 4 volumes of the Construction Industry Standards are dedicated to outline public residential standards, each for different types of housing development. For example CIS 2:1998 is for low-cost apartments and CIS 4:2005 is for low middle-cost apartments. All of public housings initiated by the government are expected to follow this standard. However there is no checking mechanism that ensures all of the housing schemes comply with their required internal space design standards.

Singapore had created a numeric hierarchical system of classification called Singapore Standard Classification of Type of Dwelling and is designed for use in collection of data that require classification of information on dwelling types. Table 5 and Chart 1 illustrate how the classification system works. The 3digit codes can be used to inform us about the dwelling class, housing typology and the nature of the house. It is suggested that such system is implemented in Malaysia so that enforcement of mandatory minimum housing standards can be monitor more effectively.

Table 5. Nomenclature system

\begin{tabular}{c|l}
\hline CODE & \multicolumn{1}{c}{ TYPE OF DWELLING } \\
\hline & \\
1 & HOUSING UNITS \\
11 & Housing and Development Board (HDB) Properties \\
111 & 1-Room Flat (HDB) \\
112 & 2-Room Flat (HDB) \\
113 & 3-Room Flat (HDB) \\
114 & 4-Room Flat (HDB) \\
115 & 5-Room Flat (HDB) \\
116 & Executive Flat (HDB) \\
117 & Housing and Urban Development Corporation (HUDC) Flat \\
118 & (excluding those privatised) \\
12 & Studio Apartment (HDB) \\
121 & Landed Properties \\
122 & Bungalow/ Detached House \\
123 & Semi-Detached House \\
13 & Terrace House \\
131 & Condominiums and Other Apartments \\
132 & Condominium (except Executive Condominium) \\
139 & Executive Condominium \\
14 & Other Apartments nec \\
141 & Other Housing Units \\
149 & Shophouse \\
Source: Singapore Standard Classification of Type of Dwelling, Jan \\
2012
\end{tabular}


Chart 1. Overview of types of dwelling

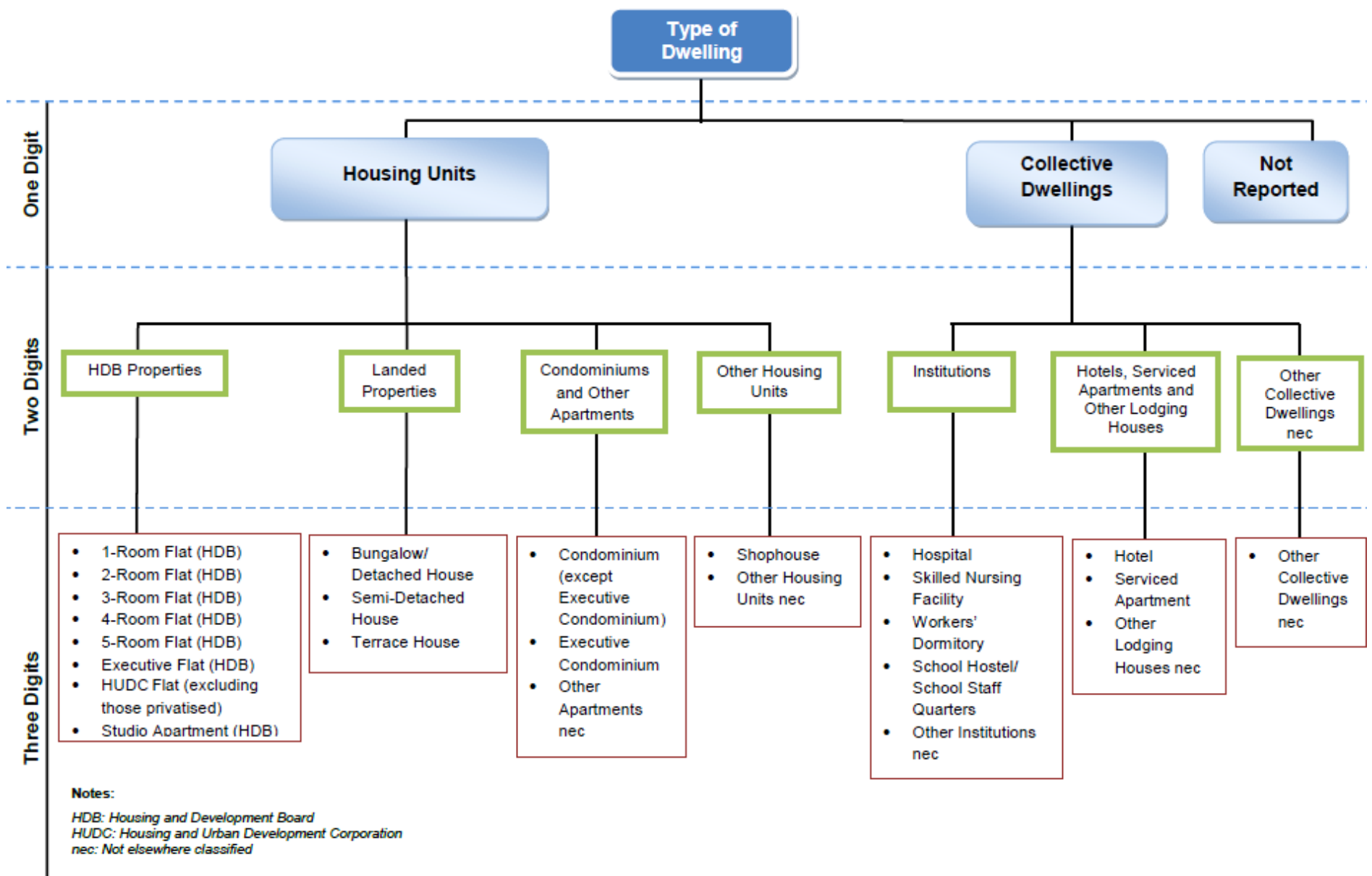

Source: Singapore Standard Classification of Type of Dwelling, Jan 2012

\section{Future trends of low-cost housing in Malaysia}

\subsection{Future housing of the nation}

Low-cost housing apartments have now been regarded as important residential concept in the urban living world-wide. It appears that due to tremendous urban growth throughout the world, there has been an urgent need to construct accommodations for a huge number of people in towns and cities around the world [17]. Goh [18] annotate the 1991 housing census that $90 \%$ of the housing stock in the country was in the form of houses, while flats or apartments accounted for only 7\%, and shop houses accounted for 3\%. However, flats and apartments are slowly emerging in major urban areas. Flats generally refer to apartments of between 500 to 700 square feet each with three bedrooms. They have bare finishing and no facilities except parking bays, the number of which may not be as many as the number of flats in any particular scheme. Unless the flats are above five stories, they are generally not equipped with lifts. Ministry of Housing and Local Government announced that, until December 2012 the number of people inhabiting strata properties is now around 6 million

\footnotetext{
a Corresponding author: ${ }^{1}$ niza_alambina@um.edu.my
}

people, accounting for $20 \%$ of the national population. It is estimated that by $2020,70 \%$ of the population will live in major urban cities throughout Malaysia [19].

This will inevitably increase the demands for strata housing in the near future. Therefore, low-cost apartments should be given the topmost priority and need to have the same psychological benefits of landed properties. They should promote safe, secure and good environment for nurturing holistic social wellbeing. It is expected that Malaysia will become a high-income nation by the year 2020 with the expected real Gross Domestic Product (GDP) to expand between 5-6 percent per annum from 2016-2020, resulting in a 7.9 percent per annum rise in Gross National Income (GNI) per capita. This economic prosperity should be trickling down efficiently and further enhancing the quality of low-cost housings.

Currently the government subsidized $30 \%$ to $75 \%$ of total construction cost for public housing units [6]. The deep subsidization by the government in financing quality low-cost housing should be seen not only as a civic responsibility but also as a long-term investment to empower the low-income households so that they could break free from the B40's bracket and subsequently, further driving economic growth of the nation and ultimately reducing the need for low-cost housings in general. Hence, improving the current space design standards of low-cost apartment (such as CIS 2:1998) does have significant importance. 


\subsection{Greater flexibility for shifts in urban demographic}

It is a paradox that most low-income households have large families and need larger units which they cannot afford [20]. The average number of people in a Malaysian household is 4 to 5 and more spaces are required for a growing family [21]. Indeed, this poses a great problem to the government planners of low-cost housing programmes since all of the low-cost housing schemes, particularly the People's Housing Project (PPR) which only provides 3-bedroom units. Consequently, household with large families are forced either to overcrowd a single room with 3 or 4 persons or to use up other spaces such as the dining/ living room, thus greatly impairing the functionality of the house.

The second demographic concern in the near future is the increasing youth and young married couple in urban area, including those under the 1Malaysia Youth City Programme. Today's Gen-Y are getting more and more flexible and prefer high-rise building as this will allow them to live near to their workplace. They usually do not require big house and are contended with having only 1 or 2 bedrooms. In fact, the government had already taken a proactive approach in catering to the need of the Gen-Y by introducing a new concept known as Transit Houses. These transit houses provide such families with a short term residence while they build up their savings to purchase their first home [10]. New space design standards should be developed for this kind of houses to avoid the problems of sub-standard construction. However, the standards can be a bit more relax.

Lastly, Burgstahler [22] defines universal design as the design of products and environments to be usable by all people, to the greatest extent possible, without the need for adaptation or specialized design. This would include the senior citizens, person with disability, pregnant ladies, children and et cetera. According to the Department of Statistic, it is foresee that the number of senior citizens in Malaysia would double in between 2010 and 2035. Senior citizens are defined as population aging above 60 years old and currently accounted for 1.8 million people or roughly $7 \%$ of the national population. However, this numbers are expected to escalate to 3.4 million people or $10 \%$ of the population by 2020 .

A study by Da Vanzo and Chan [23], illustrated that generally it is considered as a norm or tradition for most Malaysians to co-reside with their. Hence, it would only be appropriate if the current space design standards incorporate provisions on universal design in accordance to the existing Malaysian Standards such as the MS ISO/IEC GUIDE 71:2012. The future low-cost housing developments can also explore the idea of dualkey concept. A new trend currently gaining popularity in medium-cost and high-end condominium developments and is seen as an alternative way to guest extended families or the old folks but at the same time ensuring privacy and security. This would also potentially provide some protection of parents from being taken into "old folk's homes", and saving on public spending [24].

\subsection{Implementation of Industrialised Building System (IBS)}

In terms of research and development to strengthen the quality and housing construction standards, the National Housing Policy focuses on the use of latest technology and tools such as Industrialized Building System (IBS). The implementation of IBS constructions has numerous advantages in improving the quality of low-cost housing development. This include (1) being cost-effective and environmentally-friendly construction, (2) having highquality components in construction, (3) produce aesthetically-pleasing buildings that serve the purposes they were built for, (4) does not give problems to endusers (such as leaks), (5) adaptable to future needs of users through renovation or extension and (6) upholds safety and health requirements in construction [25].

It is argued that in the scenario where the government successfully implements IBS construction system in all of its public housing developments, it would result in significant decrease in construction costs. It is further argued that with the reduction of cost, increasing space standard will be more sustainable and financially feasible.

\section{Setbacks}

The issue of regulating higher standards to improve housing quality would always draw attention and criticisms from private developers since private developers are the biggest provider of low-cost housing. Private developers are profit oriented and may result in less emphasize on utility and greater concern for marketability. Currently there is a surplus of high-end housing especially apartments in the urban areas whilst majority of Malaysians income are not within the band of those who can afford such luxury. The mainstream property market will slowed down since the second quarter of 2015 as the overall economy has stepped down. However it is important to recognize the contribution of the private sector thus far. Often not highlighted is the fact that Malaysia has one of the most successful programs of housing for the poor that is the envy of developing and even some developed nations in the world. Key to this unique example of a highly successful program of low-cost housing is the substantial and active direct participation of private sector developers in the entire low-cost housing program [26].

Simple economics suggest that the cost per square metre of residential space would remain static, or fall owning to economies of scale, but larger home (with arguably greater utility) would have a bigger price tag. This would have effect of reducing affordability [12]. Cost factor will always be a major determinant of the quality of materials and specification for low-cost houses. On one hand, private developers agree and accept that certain minimum standards, particularly 
those related to safety for low-cost housing must be set, while on the other hand concern that policy makers may become over-zealous in their efforts to prove their social concern and 'over specify' [26]. Hence, one of the way forward will be to find the balance between providing adequate minimum spaces for resident satisfaction while at the same time having some economic values for private developers.

\section{Conclusions}

It can be concluded that the improvement of current space design standards is a very crucial move and should be embrace by all of the industry players to further enhance the quality of housing. Extensive researches are necessary to figure out the optimum standards, without over-specifying and would benefit not only the occupants, but also the government and the developers alike. The next step of this research will be to study the evolution and technical performance of existing internal housing standards.

\section{Acknowledgements}

The authors would like to thank the University of Malaya for funding this study through the University of Malaya Research Grant (UMRG) (Project no. RP015B15SUS) under the Sustainable Science Research Cluster (SuSci) whose support we duly acknowledge.

\section{References}

1. The World Bank. (2016, January 14). Total Population Data. Retrieved http://data.worldbank.org/country/malaysia.

2. Singh, H. \& Kilmartin, L. (1992). Housing in the Third World: Analysis and Solutions. New Delhi, India: Concept Publishing Co.

3. Habitat, U. N. (2011). Cities and climate change: Global report on human settlements 2011. London, Royaume-Uni, Etats-Unis: UN-Habitat.

4. Ahmad, F., Wan Abd Aziz, W. N. A., Hanif, N. R., \& Mohd Ahmad, I. (2011). Home Owning Democracy for the Urban Poor: A Case Study of Kuala Lumpur, Malaysia. Journal of Sustainable Development, 5(1), 13-22. http://doi.org/10.5539/jsd.v5n1p13

5. Idrus, N., \& HO, C. S. (2008). Affordable and Quality Housing Through the Low-Cost Housing Provision in Malaysia. Department of Town \& Regional Planning, Faculty of Built Environment Universiti Teknologi Malaysia Jointly organized Toyohashi University, 1-21.

6. Economic Planning Unit. (2010). Tenth Malaysia Plan 2011-2015. Putrajaya: The Economic Planning Unit, Prime Minister's Department.

7. Sulong, M. (1984). Perumahan Awam Kos Rendah di Terengganu: Isu, Masalah dan Penerimaan Masyarakat. Malaysia: Universiti Kebangsaan Malaysia.
8. Tan, S. H. (1980). Factors influencing the location, layout and scale of low-cost housing in Malaysia. In S. H. Tan, \& H. Sendut (Eds.), Public and private housing in Malaysia. Kuala Lumpur: Heinemann Educational Books (Asia) Ltd.

9. Bakhtyar, B., Zaharim, a., Sopian, K., Saadatian, O., \& Moghimi, S. (2013). Quality housing in affordable price for Malaysian low income. WSEAS Transactions on Environment and Development, 9(2), 78-91.

10. Economic Planning Unit. (2015). Eleventh Malaysia Plan 2016-2020. Putrajaya: The Economic Planning Unit, Prime Minister's Department.

11. Diener, E., \& Suh, E. (1997). Measuring Quality of Life: Economic, Social, and Subjective Indicators. Social Indicators Research, 40(1-2), 189-216.

12. Gallent, N., Madeddu, M., \& Mace, A. (2010). Z Internal housing space standards in Italy and England. Progress in Planning, 74(1), 1-52. http://doi.org/10.1016/j.progress.2010.04.001.

13. Construction Industry Standard 21998 of Malaysia

14. Uniform Building By-Law 1984 of Malaysia

15. Mohit, M. A., Ibrahim, M., \& Rashid, Y. R. (2010). Assessment of residential satisfaction in newly designed public low-cost housing in Kuala Lumpur, Malaysia. Habitat International, 34(1), 18-27. http://doi.org/10.1016/j.habitatint.2009.04.002

16. Shuid, S. (2009). Changing Structure of Low Income Housing Provision in Malaysia. HSA Conference 2009, 1-20.

17. Zehadul Karim, a. H. M. (2013). Living condition in the low cost apartments in Malaysia: An empirical investigation. Asian Social Science, 9(17), 20-29. http://doi.org/10.5539/ass.v9n17p20

18. Lee, G. B. (1997). Housing Delivery System: An Academician's Perspective. Housing the Nation: A Definitive Study.

19. Zainun, N. Y., \& Eftekhari, M. (2010). Forecasting low-cost housing demand in urban area in Malaysia using ANN, (1), 899-902.

20. Salleh, G., \& Chai, C. L. (1997). Low Cost Housing: Issues and Problems. Housing the nation: A definitive study, 215-228.

21. Isnin, Z., Ramli, R., Hashim, A. E., \& Ali, I. M. (2012). Sustainable Issues in Low Cost Housing Alteration Projects. Procedia - Social and Behavioral Sciences, 36(June 2011), 393-401. http://doi.org/10.1016/j.sbspro.2012.03.043

22. Burgstahler, S. (2015). Universal Design: Process, Principles, and Applications How to apply universal design to any product or environment. DO-IT: Disabilities, Opportunities, Internetworking, and Technology. Retrieved from http://www.washington.edu/doit/universal-designprocess-principles-and-applications

23. DaVanzo, J., \& Chan, A. (1994). Living arrangements of older Malaysians: Who co-resides with their adult children? Demography, 31(1), 95113.

24. Hamzah, M. Bin. (1997). Housing policy in Malaysia: Conditions, perspectives and Islamic 
values. $\quad$ Retrieved from http://etheses.whiterose.ac.uk/543/

25. Hamid, Z. A. \& Kamar, K. A. M. (2013). Implementing the Industrialized Building System. Housing the Nation: Policies, Issues and Prospects.

26. Chan, L. (1997). Low cost Housing: The Industry Viewpoint. Housing the Nation: A Definitive Study. 